\title{
Distribution of decapod larvae in the surface layer of an isolated equatorial oceanic archipelago: the cases of benthic Grapsus grapsus (Brachyura: Grapsidae) and pelagic Sergestes edwardsi (Dendrobranchiata: Sergestidae)
}

\author{
Manoela Costa Brandão • Andréa Green Koettker • \\ Andrea Santarosa Freire
}

Received: 5 December 2011 / Revised: 8 May 2012/Accepted: 22 May 2012/Published online: 8 June 2012

(C) Springer-Verlag and AWI 2012

\begin{abstract}
Two different decapod larval assemblages inhabit the marine environment of Saint Paul's Rocks, differentiating the inlet from the surrounding oceanic waters. Larvae of the crab Grapsus grapsus and of the holopelagic shrimp Sergestes edwardsi are abundant in superficial waters of the archipelago and have previously been shown to be good indicators of the inlet and adjacent oceanic waters, respectively. We investigated the horizontal, diel and temporal distribution of these species at Saint Paul's Rocks. Horizontal surface hauls were conducted from 2003 to 2005, in the inlet and at four increasing distances from the archipelago, in the morning and at night, using a $200-\mu \mathrm{m}$ mesh net. Larvae of G. grapsus were identified in samples from all expeditions and abundance was found significantly higher at night in the inlet site. Only larvae in the first zoeal stage were found in samples, highlighting the importance of the area for this species reproduction. On the contrary, the distribution of larvae of $S$. edwardsi was typical of a holopelagic species, which are permanent residents of the water column and spawn in oceanic areas, indicating that the islands are of little influence to them.
\end{abstract}

Communicated by Heinz-Dieter Franke.

M. C. Brandão $(\bowtie) \cdot$ A. S. Freire

Departamento de Ecologia e Zoologia,

Universidade Federal de Santa Catarina,

Florianópolis 88010-970, Brazil

e-mail: manoelacb@yahoo.com.br

A. G. Koettker

Instituto Oceanográfico, Universidade de São Paulo,

São Paulo 05508-120, Brazil
Keywords Larvae - Decapoda - Meroplankton . Holoplankton · Distribution · Oceanic island

\section{Introduction}

During their pelagic period, larvae are exposed to the variation of many ecological factors that influence their chances of survival, development, dispersion and recruitment (Anger 2001). The abundance and distribution of decapod larvae in marine habitats are influenced by factors such as temperature, salinity, light, mortality rates of each stage, food availability, vertical migration, distance from spawning sites, the speed and direction of currents and the duration of their pelagic period (e.g. Sastry 1983; Anger 2001; Queiroga and Blanton 2004).

The presence of larvae of certain species in a given area indicates the presence of the corresponding adult species (Boltovskoy 1981), while the presence of the first larval stage indicates that reproduction occurs in that area (Anger 2001).

Larval dispersion occurs when: (1) the larval stages found are more developed as time from the hatching larval stage and distance from the parental population increase and (2) the first larval stage encounters a surface current from the initial parental population, where abundance diminishes progressively heading seaward. On the other hand, if all stages of development are only found present near the parental site throughout the water column, this leads to larval retention (Queiroga and Blanton 2004; Fogarty and Botsford 2006; Cowen and Sponaugle 2008). Recent work suggests that retention of larvae in the natal habitat is more frequent than suspected and, therefore, that populations may be less open (or more closed) than originally thought (Sponaugle et al. 2002; Levin 2006; Morgan 
et al. 2009). Most recent articles published about dispersal emphasize retention, but tend to ignore those larvae that are not retained. If even a small fraction of these successfully recruit elsewhere, their significance for connectivity may be great (Levin 2006).

Available information indicates that larvae of virtually all decapod species perform some kind of diel vertical migration, especially nocturnal migration (Queiroga and Blanton 2004). This occurs when larvae descend to greater depths during the day, avoiding exposure to visual predators, ultraviolet rays and unwanted physical and chemical parameters, then rising to the surface mainly at night to search for food. To a certain degree, the ability to control the vertical position in the water column allows for control in the extent and direction of horizontal dispersion (Queiroga and Blanton 2004).

Islands usually cause disruption in the flows of oceanic systems, where mainly advective processes cause variations in biomass and biological production in the adjacent regions (Boehlert et al. 1992). Saint Paul's Rocks is a small group of rock points and islands that rise from abyssal depths, from about $4,000 \mathrm{~m}$, up to a few meters above the surface (Edwards and Lubbock 1983a). The combination of this abrupt topography with the local currents can create complex mechanisms of vertical migration and topographic blockage of zooplankton and micronekton (Genin 2004).

Two different decapod larval assemblages inhabit the Saint Paul's Rocks, differentiating the inlet from the surrounding oceanic waters (Koettker et al. 2010). In this study, larvae of G. grapsus Linnaeus, 1758 and Sergestes edwardsi Krøyer, 1855 were treated as representatives of two different functional groups, determined by their adult habitats: benthic or pelagic, respectively. The larvae of the species Grapsus grapus had the highest relative abundance in the inlet waters, while larvae of $S$. edwardsi presented the highest relative abundance and frequency of occurrence in the surrounding waters of Saint Paul's Rocks (Koettker et al. 2010). The larval distribution and abundance pattern observed during the 4 months (distributed along 1 year of sampling at Saint Paul's Rocks) for G. grapsus was similar to the pattern observed for other benthic decapods, such as Plagusia depressa Fabricius, 1775, Platypodiella spectabilis Herbst, 1794 and other species of Grapsidae, Xanthidae and Alpheidae. The pattern exhibited by S. edwardsi was also observed for Sergestes curvatus Crosnier and Forest, 1973, Sergestes henseni Ortmann, 1893 and for the genera Gennadas Bate, 1881 and Lucifer Thompson, 1829 (Koettker et al. 2010).

The rocky shore crab G. grapsus is a semi-terrestrial and carnivorous species that mainly occurs in oceanic islands. This species is very abundant at the Brazilian oceanic islands (Saint Paul's Rocks, Rocas, Fernando de Noronha and Trindade). It also occurs at the Caribbean Islands, along the Eastern Pacific coastline and islands (from Baja California to northern Chile) and at the Galapagos Islands (Freire et al. 2011). The first larval stage of this species is the only stage that has been described to date (Guerao et al. 2001). G. grapsus dominates the benthic macrofauna of the emerging area of Saint Paul's Rocks (Freire et al. 2011), where reproduction exclusively occurs and dispersion depends on the marine currents.

Sergestes edwardsi is an oceanic pelagic species and has been recorded at depths ranging from $5,100 \mathrm{~m}$ up to the surface. Because of their swimming ability and large size, adults may be considered either micronekton or macroplankton (Pakhomov and Froneman 2000); therefore, we refer to them as holopelagic herein. Its distribution is restricted to the Atlantic, ranging from Newfoundland (Canada) to Rio Grande do Norte (Brazil), in the Western Atlantic; and from Madeira Island (Portugal) to Angola, in the Eastern Atlantic (Melo 1996). At Saint Paul's Rocks, adults of this species were sampled near surface during night and at greater depths during the day (Holthuis et al. 1980).

This study aims to describe the distribution of larvae of G. grapsus and S. edwardsi in the surface waters off Saint Paul's Rocks, since they could serve as models for other benthic and pelagic decapod species, respectively. We also discuss the dispersion and retention of these species and their diel variation.

\section{Materials and methods}

\section{Study area}

Saint Paul's Rocks is one of the smallest and most isolated groups of oceanic islands in the world. It is the highest and steepest point of the Saint Peter and Saint Paul massif, linked to the Atlantic Mid-Ocean ridge, close to the Equator $\left(0^{\circ} 55^{\prime} \mathrm{N}\right.$ and $\left.29^{\circ} 21^{\prime} \mathrm{W}\right)$. This massif is about $90 \mathrm{~km}$ long and $21 \mathrm{~km}$ wide at the 3,000 m depth contour (Sichel et al. 2008). The archipelago has an emerged area of about $16,000 \mathrm{~m}^{2}$, extends up to $400 \mathrm{~m}$ and can reach a maximum height of $18 \mathrm{~m}$ above sea level. It is located at approximately $500 \mathrm{~km}$ from the nearest archipelago (Fernando de Noronha), 1,000 km from the Brazilian coast and 1,890 km from Senegal, on the African Coast (Edwards and Lubbock 1983a; Feitoza et al. 2003) (Fig. 1).

The four main islands (Belmonte, St. Paul's, St. Peter's and Barão de Teffé) are separated by narrow channels and form a horseshoe-shaped inlet with depths ranging from 4 to $25 \mathrm{~m}$ (Feitoza et al. 2003) (Fig. 2). There is a lighthouse and a scientific station housing Brazilian researchers on Belmonte Island, which comprises the largest emerged area of the four. 
Fig. 1 Location of Saint Paul's Rocks and other oceanic islands in the Tropical Atlantic, between South America and Africa

Fig. 2 Map showing the main islands of Saint Paul's Rocks (is.) and the inlet
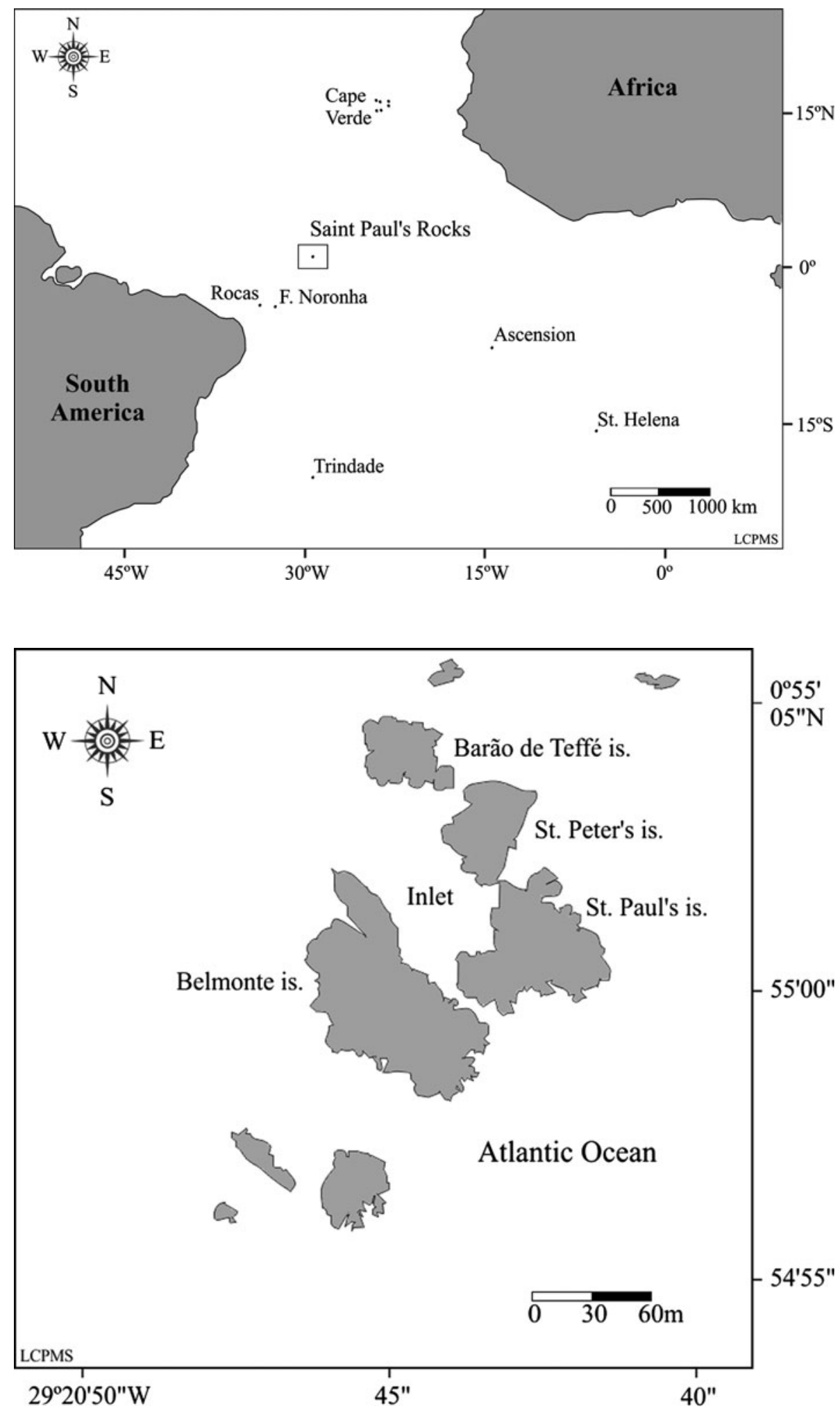

March and November/December 2004; January, May and July 2005. During each expedition, 18 plankton samples were collected at four distances from Belmonte Island, with an equal number of replicates sampled at dawn/during the morning (between 6.30 a.m. and midday) and at dusk/
Between April 2003 and July 2005, eight expeditions were conducted at Saint Paul's Rocks during which 186 samples were collected in April, August and November 2003; 
during the night (between 6.00 p.m. and 10.14 p.m.). In addition, six plankton samples were taken in the inlet (three at dawn/morning and three at dusk/night), with the exception of April 2003. Those samples collected around the archipelago (outside the inlet) were considered as 'open ocean'. Although they correspond to the same expedition, November and December 2004 were separated for some analyses because the open ocean samples were collected in late November, whereas the inlet samples were collected in early December.

The open ocean samples were collected at four different distances from Belmonte Island: D1 $(<500 \mathrm{~m})$; D2 (between 501 and 1,200 m); D3 (between 1,201 and 2,000 m) and D4 (>2,001 m) (Fig. 3).

Horizontal surface plankton tows lasting $10 \mathrm{~min}$ were performed with a conical-cylindrical net with a 50-cmdiameter mouth and $200-\mu \mathrm{m}$ mesh, coupled to a General Oceanics flowmeter. At each sampling station, measurements were taken of the surface temperature (thermometer) and salinity (refractometer) and the latitude and longitude coordinates (GPS) were recorded. All samples were preserved in $4 \%$ buffered seawater-formaldehyde solution. Some samples were sub-sampled with a Folsom splitter (McEwan et al. 1954) in fractions that varied from $1 / 2$ to $1 / 32$.

Larvae of G. grapsus and S. edwardsi were identified according to Guerao et al. (2001) and Gurney and Lebour (1940), respectively. Identification was conducted under stereoscopic and optical microscopes.
Data analysis

Data on larvae of G. grapsus were analysed separately for the inlet and the open ocean by performing an analysis of variance (ANOVA), due to the large difference between the abundance figures for each habitat. Data on larvae of S. edwardsi in the two habitats were analysed together in the ANOVA since they fell within the same range of abundance. Only two distances from Saint Paul's Rocks were considered in the ANOVA for both species: D1 $(<500 \mathrm{~m})$ and $\geq$ D3 $(>1,201 \mathrm{~m})$ because these distances had the same number of replicates for all months and day/ night periods. Data for all distances were only used for the one-way ANOVA of G. grapus abundances collected at night.

Three-way ANOVA was done to test the effect of distance, month and day period on the abundance of larvae of S. edwardsi in both the inlet and the open ocean. A twoway ANOVA was done to test the effects of the month and day period on the abundance of larvae of G. grapsus in the inlet and also to test the effect of month and distance on abundance in the open ocean. One-way ANOVA was done to investigate the effect of distance on the abundance of larvae of G. grapsus in samples collected at night in both the inlet and the open ocean. Biological data were logtransformed $(x+1)$. The Shapiro-Wilks and Bartlett tests were applied a priori and the Tukey's test a posteriori (Zar 1996; Underwood 2006). These tests were conducted using STATISTICA 7 software.
Fig. 3 Locations of the 186 samples collected in the inlet and the open ocean over a total of eight expeditions. Circles indicate distances from Belmonte Island (dashed white: $500 \mathrm{~m}$, dashed black: 1,200 m and solid black: 2,000 m). D1: $<500 \mathrm{~m}$, D2: 501-1,200 m, D3: $1,201-2,000 \mathrm{~m}$,

D4: $>2,001 \mathrm{~m}$

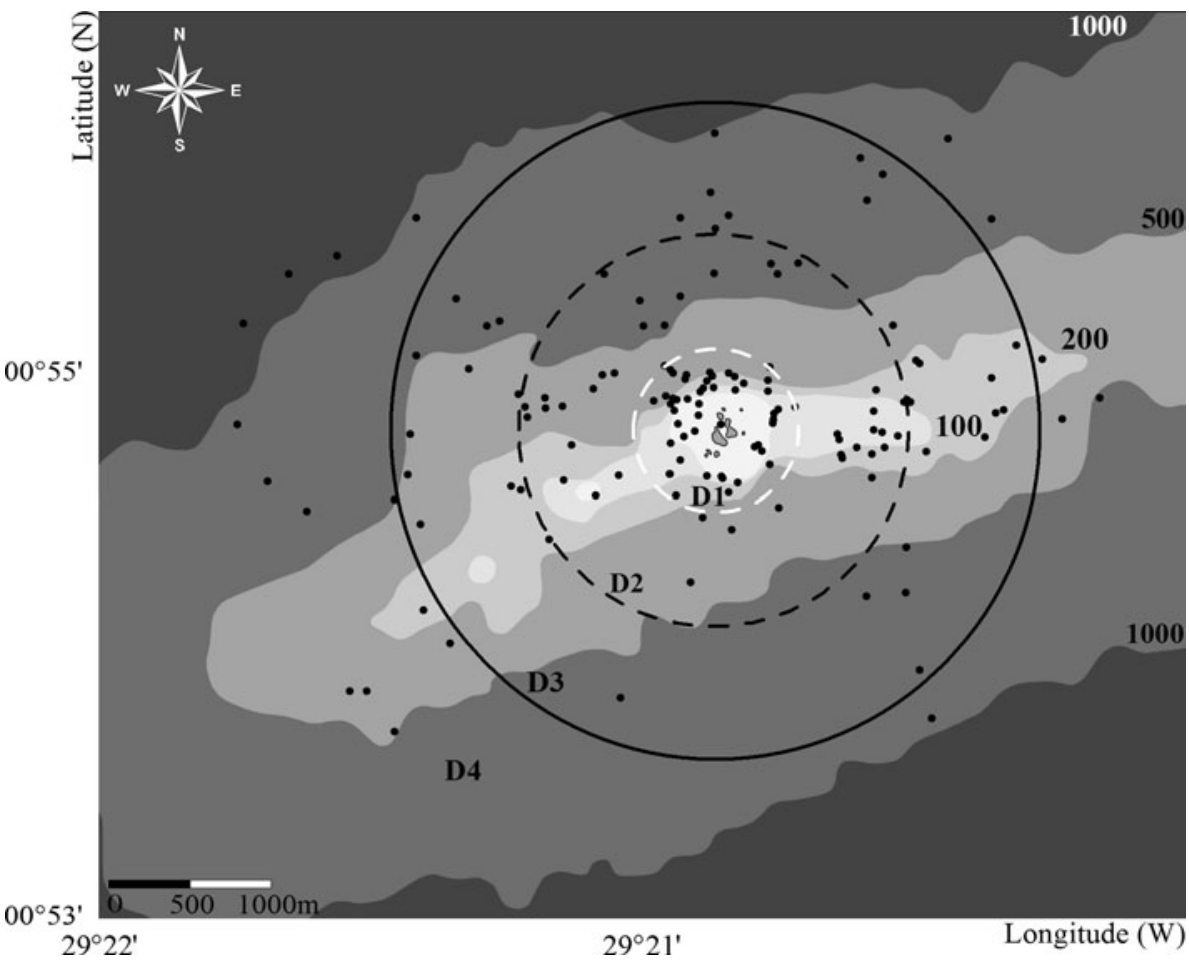


Golden Software's Surfer 8 was used to construct distribution maps showing the larval abundance of G. grapsus and $S$. edwardsi by plotting the abundance at each sampling station.

\section{Results}

The mean water temperature varied from $26.4^{\circ} \mathrm{C}$ in November to $28.7^{\circ} \mathrm{C}$ in January. August, November and July presented the lowest mean temperatures $\left(<27.5^{\circ} \mathrm{C}\right)$ for both periods of the months in which samples were collected, while all other months had mean temperatures higher than $27.5{ }^{\circ} \mathrm{C}$. Salinity varied from 36.0 in April and May to 37.7 in July.

\section{Grapsus grapsus}

Out of a total of 186 samples collected in the surface waters off Saint Paul's Rocks over eight expeditions (144 from the open ocean and 42 from the inlet), the larvae of G. grapsus were captured in 47 samples, 27 from the inlet and 20 from the open ocean. Thirty-nine of these 47 samples were collected at night, while just 8 were day samples. Larvae of $G$. grapsus occurred in all samples from the inlet collected at night, with abundance values ranging from 24 to 8,018 larvae $/ 100 \mathrm{~m}^{3}$. All larvae of this species collected in samples from this study were in the first larval stage.

Larvae of G. grapsus occurred in only $14 \%$ of open ocean samples, ranging from 2 to 175 larvae $/ 100 \mathrm{~m}^{3}$. Larvae of $G$. grapsus were not found during the day in any of the months at D1 or at $\geq$ D3. During the day, these larvae only occurred in two samples, both collected at D2, one in January and the other in May, with abundance of 1 and 17 larvae $/ 100 \mathrm{~m}^{3}$, respectively.

The mean larval abundance in the inlet at night $\left(1,569 \pm 438\right.$ larvae/100 $\left.\mathrm{m}^{3}\right)$ was much higher than under other conditions. At night, we observed a trend where the mean larval abundance decreased as sampling distance from Saint Paul's Rocks increased. Mean abundance in daytime inlet samples was $18 \pm 10$ larvae $/ 100 \mathrm{~m}^{3}$, which is comparable with the abundance observed at D1 at night $\left(14 \pm 7\right.$ larvae/100 $\left.\mathrm{m}^{3}\right)$ (Fig. 4).

When we tested the spatial variation of the abundance of larvae of $G$. grapsus collected at night during all months, the results showed that abundance was significantly higher in the inlet than in samples collected at all open ocean distances (degrees of freedom $=4 ; F=82.7 ; p=0.00$; error degrees of freedom $=88$ ) (Fig. 4).

When the open ocean samples were analysed separately, G. grapsus larval abundance was significantly higher in

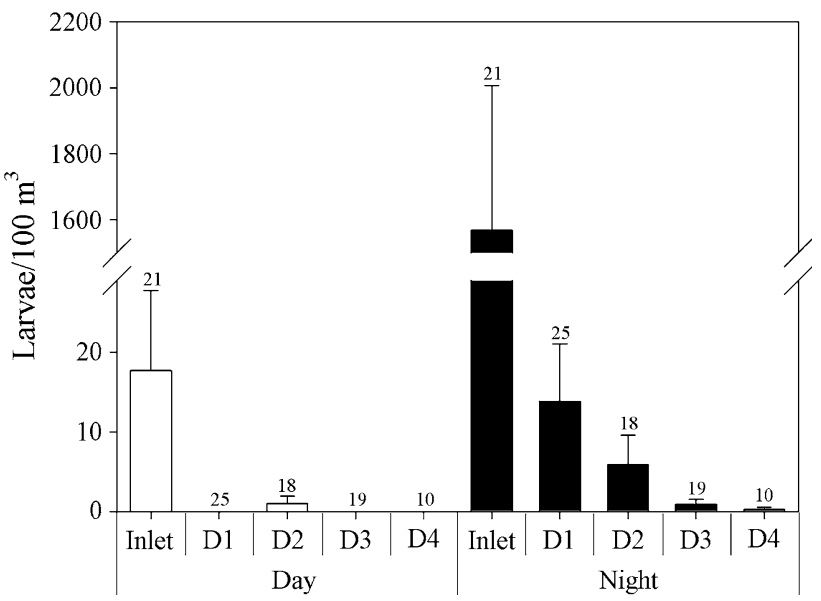

Fig. 4 Abundance (mean + se) of larvae of G. grapsus collected in the inlet and at all distances $(D 1:<500 \mathrm{~m}, D 2: 501-1,200 \mathrm{~m}, D 3$ : 1,201-2,000 m, D4: >2,001 m) during the day and at night in all sampling months. Figures above error bars indicate the number of samples included in the analysis

Table 1 Two-way ANOVA to test the effects of temporal (F1), spatial (F2 for the open ocean) and diel (F2 for the inlet) factors and their interaction on the abundance of larvae of $G$. grapsus sampled at night in both the open ocean and inlet, showing $\mathrm{F}$ values

\begin{tabular}{lllll}
\hline Degrees of freedom & $\begin{array}{l}\text { Temporal } \\
7\end{array}$ & $\begin{array}{l}\text { Spatial/ } \\
\text { diel } \\
1\end{array}$ & $\begin{array}{l}\mathrm{F} 1 \times \mathrm{F} 2 \\
7\end{array}$ & $\begin{array}{l}\text { Error degrees } \\
\text { of freedom }\end{array}$ \\
\hline $\begin{array}{c}\text { G. } \text { grapsus_open } \\
\text { ocean (only night) }\end{array}$ & $3.1^{*}$ & $9.9^{* *}$ & $1.5^{\mathrm{ns}}$ & 32 \\
\begin{tabular}{c} 
G. grapsus_inlet \\
\hline
\end{tabular} & $2.8^{*}$ & $163.8^{* *}$ & $1.3^{\mathrm{ns}}$ & 28 \\
\hline
\end{tabular}

For spatial variation, we assessed D1 and $\geq$ D3. D2 was not considered since the number of replicates was not equivalent to the remaining distances, and D4 was included in the category $\geq \mathrm{D} 3$

$* p<0.05, * * p<0.01$, ns nonsignificant

May compared with November 2003 and January. With regard to distance, D1 had significantly higher larval abundance than D3 (Table 1 and Fig. 5).

Significant variation between months was also detected in the inlet, where larval abundance was significantly lower in November than in July. The histogram shows that fewer larvae of $G$. grapsus were collected in November than the other months and that May presented the highest mean larval abundance in the inlet. With regard to diel variation, larval abundance was significantly higher at night (Table 1 and Fig. 6).

The distribution map of larvae of $G$. grapsus illustrates the higher concentrations of larvae in the inlet and at D1, with few larvae at the most distant stations. The larvae sampled at D2 were collected to the east and west of Saint Paul's Rocks (Fig. 7). 


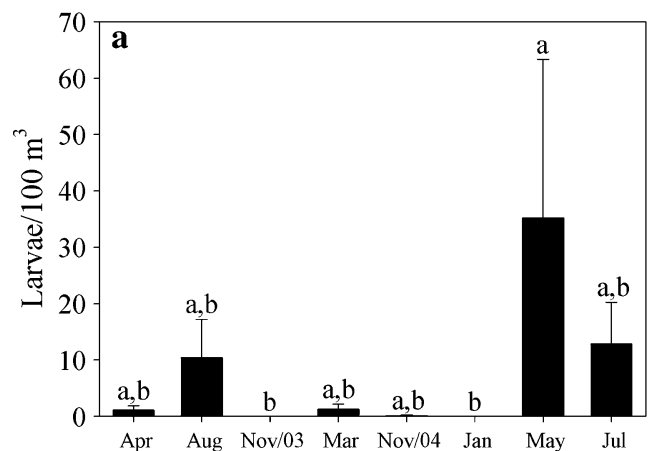

Fig. 5 Abundance (mean + se) of larvae of G. grapsus collected in the open ocean $(D 1:<500 \mathrm{~m}, \geq D 3:>1,201 \mathrm{~m})$ at night, illustrating ANOVA and Tukey's test results shown in Table 1 (different letters represent significantly different means): a temporal variation with

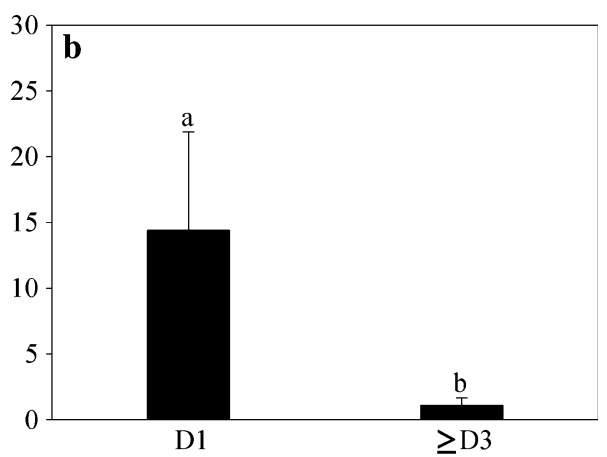

pooled data from day and night samples collected in both distances and $\mathbf{b}$ spatial variation with pooled data from day and night samples collected in all months
Fig. 6 Abundance (mean + se) of larvae of $G$. grapsus collected in the inlet, illustrating ANOVA and Tukey's test results (different letters represent significantly different means): a temporal variation with pooled data from day and night samples and $\mathbf{b}$ diel variation with pooled data from all months
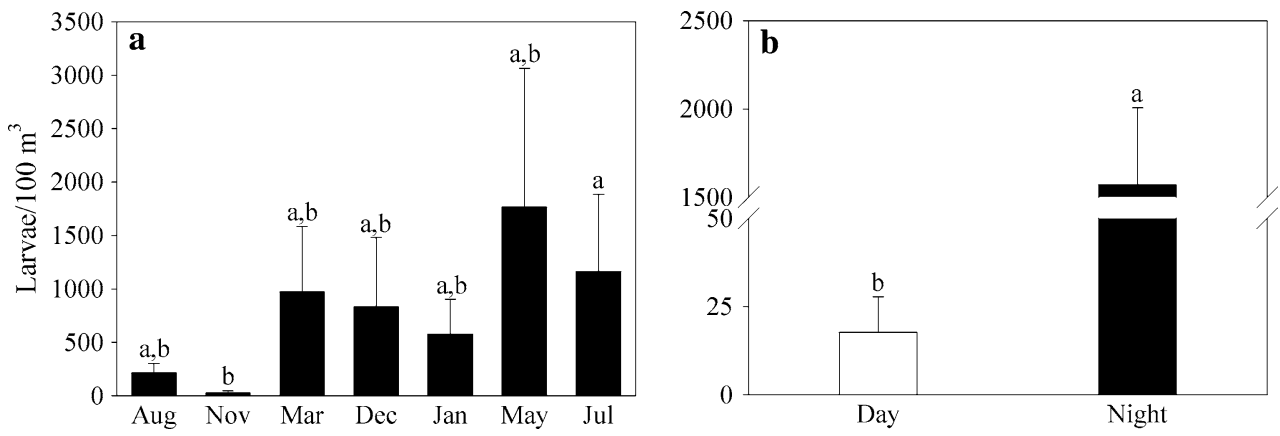

\section{Sergestes edwardsi}

Larvae of $S$. edwardsi were present in 61 samples, 9 from the inlet and 52 from the open ocean. Forty-one of these were night samples and 20 were day samples. Larvae of S. edwardsi occurred in $33 \%$ of open ocean samples and $21 \%$ of inlet samples. Larval abundance ranged from zero to 35 larvae $/ 100 \mathrm{~m}^{3}$ in the open ocean and from zero to 8 larvae $/ 100 \mathrm{~m}^{3}$ in the inlet. Larvae of this species were identified in all mysis stages (I, II and III). Furthermore, protozoeae II and III of the genus Sergestes, and protozoeae I and decapodits of Sergestidae were also identified. Some of these were probably larvae of $S$. edwardsi.

When all months were analysed together, larvae of S. edwardsi had highest mean abundance in D1 at night. The magnitude of larval abundance in the inlet, in the open ocean and in the day periods was the same. Larvae of this species showed a trend of being found farthest from the archipelago during the day and closest at night (Fig. 8).

When the differences between months were analysed, the ANOVA results for this species indicated significant interaction between temporal, spatial and diel factors, with the highest mean abundance found at night at distance $\geq \mathrm{D} 3$ (Table 2 and Fig. 9).

The highest abundance of larvae of $S$. edwardsi was found in samples taken at approximately 1,200 m west of
Saint Paul's Rocks. In most samples in which larvae of this species occurred, abundance was lower than 10 larvae/ $100 \mathrm{~m}^{3}$. Larvae were sampled at all distances from the open ocean and in the inlet (Fig. 10).

\section{Discussion}

The temperature and salinity values reported in this study and those recorded by Koettker et al. (2010) 1 year earlier are similar to those that have been found previously in the area from in situ and remote sensing observations (Pérez et al. 2005; Macedo-Soares et al. 2012). These values are compatible with the characterization of Tropical Surface Water, described as the dominant water mass in the surface layer of the area, which presents temperature and salinity of about $27.0^{\circ} \mathrm{C}$ and 36.0, respectively (Stramma and Schott 1999; Medeiros et al. 2009).

The presence of larvae of G. grapsus in all samples and the high abundance figures found at night in the inlet, demonstrate a predominance of nocturnal spawning. Preference of spawning during the night has been documented for several benthic species and is related to the lower predation rates, favouring the survival of newly hatched larvae (e.g. Christy 1982; Yamaguchi 2001). Ovigerous females of G. grapsus were caught during all seasons at 
Fig. 7 Abundance distribution of larvae of G. grapsus (larvae/ $100 \mathrm{~m}^{3}$ ) in the 186 samples collected in the inlet and in the open ocean. Circles indicate distances from Belmonte Island (dashed white: $500 \mathrm{~m}$, dashed black: 1,200 $\mathrm{m}$ and solid black: 2,000 m). D1: $<500 \mathrm{~m}$, D2: $501-1,200 \mathrm{~m}, \mathrm{D3}$ : 1,201-2,000 m, D4: >2,001 m

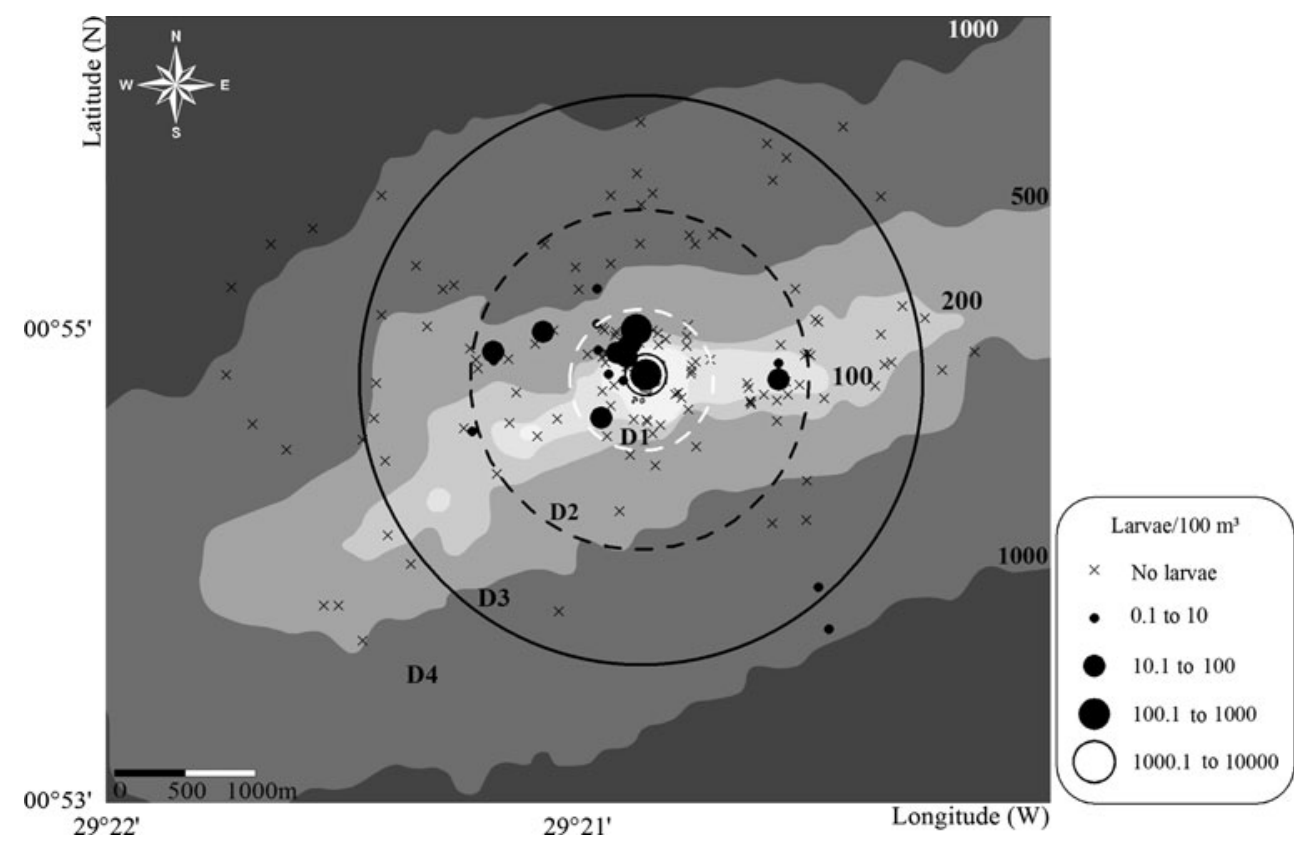

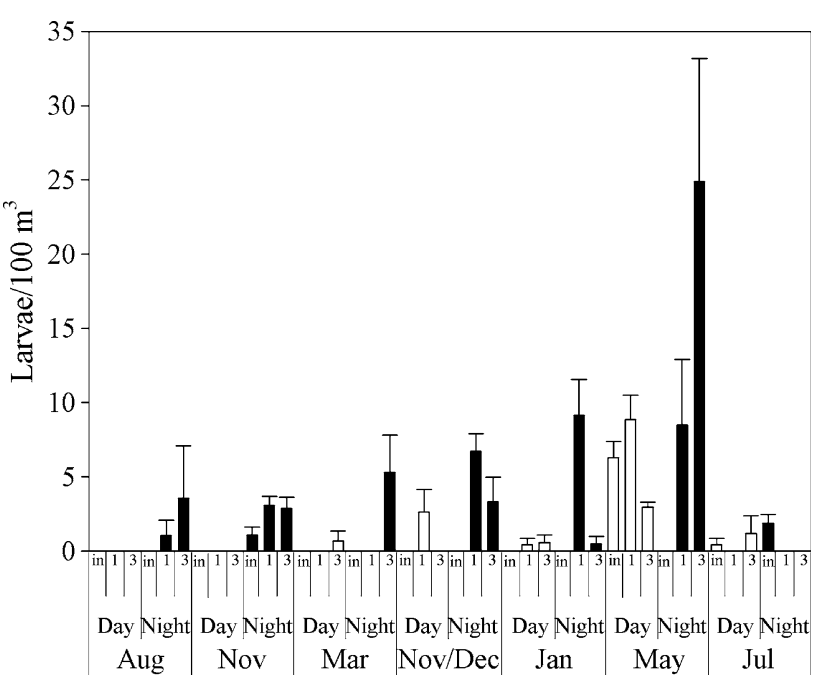

Fig. 9 Abundance (mean + se) of larvae of S. edwardsi collected in the inlet (in) and in the open ocean (1: D1: $<500 \mathrm{~m}, 3: \geq D 3:>1,201 \mathrm{~m})$, illustrating ANOVA results

and the high abundance observed in the inlet suggest that larvae of G. grapsus are an important food resource for planktivorous fish that inhabit the area, contributing to the pelagic marine food chain and acting as a keystone species in this ecosystem. The contribution of crab larvae for the pelagic food chain has already been recorded in the mangrove/platform relationship (Schwamborn et al. 1999) and in very high concentrations $\left(100-100,000\right.$ larvae/100 $\left.\mathrm{m}^{3}\right)$ of newly hatched larvae of Pachygrapsus transversus Gibbes, 1850 at a tropical rocky shore (Flores et al. 2007). 
Table 2 Three-way ANOVA to test the effects of temporal (F1), spatial (F2) and diel (F3) factors and their interactions on $S$. edwardsi larval abundance sampled in the inlet and in the open ocean, showing $F$ values

\begin{tabular}{llllllll}
\hline Degrees of freedom & $\begin{array}{l}\text { Temporal } \\
6\end{array}$ & $\begin{array}{l}\text { Spatial } \\
2\end{array}$ & $\begin{array}{l}\text { Diel } \\
1\end{array}$ & $\begin{array}{l}\mathrm{F} 1 \times \mathrm{F} 2 \\
12\end{array}$ & $\begin{array}{l}\mathrm{F} 1 \times \mathrm{F} 3 \\
6\end{array}$ & $\begin{array}{l}\mathrm{F} 2 \times \mathrm{F} 3 \\
2\end{array}$ \\
\hline S. edwardsi & $22.7^{* *}$ & $17.6^{* *}$ & $30.4^{* *}$ & $6.1^{* *}$ & $3.4^{* *}$ & $10.9^{* *}$ \\
\hline
\end{tabular}

Error degrees of freedom $=84$

$* * p<0.01$

Fig. 10 Abundance distribution of larvae of $S$. edwardsi (larvae/ $\left.100 \mathrm{~m}^{3}\right)$ in the 186 samples collected in the inlet and in the open ocean. Circles indicate distances from Belmonte Island (dashed white: $500 \mathrm{~m}$, dashed black: 1,200 m and solid black: 2,000 m). D1: $<500 \mathrm{~m}$,

D2: $501-1,200 \mathrm{~m}$,

D3: 1,201-2,000 m,

D4: $>2,001 \mathrm{~m}$

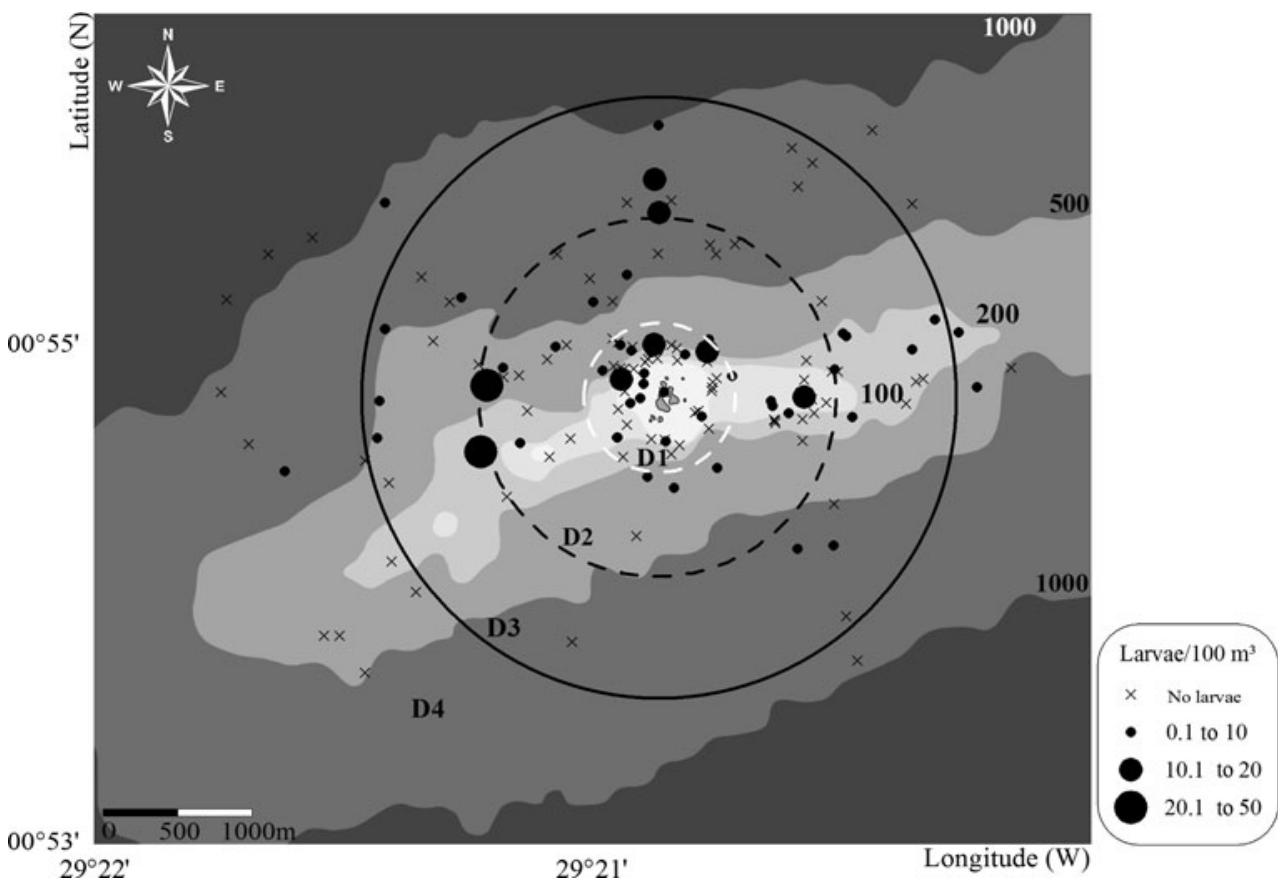

An adult population of $G$. grapsus has existed on the emerged rocks of Saint Paul's Rocks since Charles Darwin's first reports on the area until the present day (e.g. Holthuis et al. 1980; Freire et al. 2011). Although we did not conduct vertical or oblique hauls in order to sample deeper layers, the gradual decrease in abundance of larvae of $G$. grapsus as the distance from the archipelago increased and because only the first larval stage were sampled lead one to believe that the parent population of these larvae is the Saint Paul's Rocks population. In fact, oblique tows sampling the $200 \mathrm{~m}$ water column at the Canary Islands recorded much lower values of Grapsidae larvae than those at Saint Paul's Rock's (Landeira et al. 2010). In that study, larvae of the benthic Calcinus tubularis Linnaeus, 1767 and Scyllarides latus Latreille, 1802 were sampled in the third zoeal stage, but taking into account long distances to other upstream archipelagos and low densities of larvae. Here, the authors proposed that the most probable origin of the larvae was the Canary Islands themselves. Off the California coast, most of the early larval stages $(92 \%)$ of 45 crustacean species were also most abundant close to the adult habitat, up to $6 \mathrm{~km}$ from the shore (Morgan et al. 2009).

Although so far only the first larval stage of G. grapsus is known, the complete larval development of other Grapsidae species has been described (e.g. Cuesta and Rodríguez 2000; Cuesta et al. 2011) where the duration of their zoeal phase varies from about 30-60 days. Furthermore, the newly hatched larvae remain in the zoeal I stage for about 4 days before moulting to their next larval stage. This being said, it is unlikely that these larvae of G. grapsus spawned anywhere else, since Saint Paul's Rocks is over $500 \mathrm{~km}$ from the nearest archipelago (Fernando de Noronha). Many benthic marine populations have only a portion of their recruitment 'subsidized' from external sources (Pascual and Caswell 1991). In addition, the more isolated a site, the more likely it is that the present population is maintained entirely by self-recruitment (Sponaugle et al. 2002). Marine populations around oceanic islands with no clear source of recruitment could be washed away if mechanisms to retain and maintain the larvae near their natal populations are absent (Landeira et al. 2009). 
If we assume that a larva behaves in the same way as an inert particle and that the speed at which the equatorial branch of the South Equatorial Current (SEC) reaches Saint Paul's Rocks $(5.6 \mathrm{~km} / \mathrm{h})$ (Edwards and Lubbock 1983b) is constant, we could conclude that it is possible for a larva in zoeal stage I to reach Fernando de Noronha after 4 days. However, the small percentage $(0.04 \%)$ of larvae of G. grapsus found $2 \mathrm{~km}$ away from Saint Paul's Rocks (D4) indicates that there is no connectivity between the population of this archipelago and other oceanic islands of the Equatorial Atlantic. In an efficient connection, for example, between coast/platform/coast, larval dispersal can reach distances up to $15 \mathrm{~km}$, as found along the northeast coast of Brazil (Schwamborn et al. 1999).

Marine populations range from entirely closed (selfsustaining populations, such as endemic island species where $100 \%$ of recruitment is due to the settlement of offspring produced by that population) to fully open populations, recruiting only a relatively small proportion of their own offspring and receiving a high number of recruits from other populations (Sponaugle et al. 2002). It has become increasingly apparent that larvae are more likely to recruit closer to natal populations and in higher abundances than generally realized (Morgan et al. 2009; Morgan and Fisher 2010). Islands normally have coastal retention zones that allow for maintenance of the larvae near their natal sites, a result of the interaction between the main current flow and topographic relief (capes, banks, headlands and embayments) (Landeira et al. 2009). In Saint Paul's Rocks, the inlet must act as a site not only for retention, but must also be a location where the larvae of benthic species can maximize growth and survival.

Although late larvae were not found in samples, the geographical isolation of the area and the low levels of larval abundance found at the points farthest from the archipelago indicate that some type of physical process may be maintaining the larvae of $G$. grapsus in the Saint Paul's Rocks region, while another type of biological process causes late larvae to inhabit the deepest layers of the water column. Late larvae tend to keep to deeper waters, while initial larvae are most abundant in surface waters (Queiroga and Blanton 2004). Eddies serve as retention-favourable areas for a variety of larvae in regions near islands (Sponaugle et al. 2002; Queiroga and Blanton 2004), increasing plankton production by pumping nutrients in the euphotic zone (Arístegui et al. 1994), thereby providing a suitable environment for larval survival. However, little is known about this type of phenomenon in the Saint Paul's Rocks area.

Larvae of $S$. edwardsi were more frequent in the open ocean samples. Larvae and adults of Sergestidae are fully adapted to areas of the open ocean (Omori 1974). The abundance figures for S. edwardsi at Saint Paul's Rocks were similar to figures that have been reported for other dominant species of Sergestidae from other oceanic regions (e.g. Calazans 1994; Landeira et al. 2009; Mujica et al. 2011). Dendrobranchiata larvae, mainly represented by Sergestidae, were dominant around Saint Paul's Rocks at different stages of development (Koettker et al. 2010). Larvae of the genus Sergestes occurred in oceanic stations around Easter Island (Mujica 2006). This is probably related to the distribution of adults in pelagic oceanic waters, where they spawn (Landeira et al. 2009).

The relatively homogeneous distribution across the different sampling stations suggests that larvae of $S$. edwardsi can benefit from the proximity of the archipelago, but since they are independent of any substrate, they did not exhibit a strong association with the archipelago. Larvae distribution of Sergestidae was also found homogeneous around Easter Island (Mujica 2006).

The larvae of benthic species also exhibited the opposite tendency of pelagic species around the Canary Islands, in that the larvae of benthic species decreased in abundance in offshore directions, while those of pelagic species increased. While the distribution of Gennadas spp., Sergestes cornutus Krøyer, 1855 and S. atlanticus H. Milne Edwards, 1830 was a clear example of the pelagic pattern, other species were strongly associated with the area close to the island [e.g. Galathea intermedia Liljeborg, 1851, Pagurus spp., Munida spp. and Alpheus macrocheles Hailstone, 1835] (Landeira et al. 2009).

It is likely that the populations of other local benthic decapods (Plagusia depressa, Platypodiella spectabilis and other Grapsidae, Xanthidae and Alpheidae) follow the same pattern as G. grapsus, while pelagic decapods (Sergestes curvatus, Sergestes henseni and the genera Gennadas and Lucifer) are distributed in a similar manner to that of $S$. edwardsi.

In summary, the two species analysed, once adults inhabit different biological compartments, resulting in the maintenance of different ecological adaptations. Species with high parental investment, such as G. grapsus, have increased survival of eggs, larvae and even juveniles, which favours self-recruitment, promoting retention near the parental population. On the other hand, species whose fertilized eggs are spawned, like Sergestidae shrimps, have relatively smaller eggs and larvae with less ability to remain close to the source population (Sponaugle et al. 2002). The results of this study suggest that there is a possible retention mechanism acting on the larvae of meroplanktonic species at Saint Paul's Rocks, while larvae from holopelagic species are widely distributed through the oceanic area around the archipelago. Although later larvae of G. grapsus were not recorded in the $200 \mathrm{~m}$ water layer off the Canary Islands (Landeira et al. 2010), vertical hauls combined with descriptions of currents should elucidate the retention process. 
Acknowledgments This research was supported by the Coordenação de Aperfeiçoamento de Pessoal de Nivel Superior (CAPES) and the Secretaria de Estado da Educação de Santa Catarina (grants awarded to the first author), the Fundação de Amparo a Pesquisa do Estado de São Paulo (FAPESP) (Grant 05/58085-5, awarded to the third author), the Conselho Nacional de Desenvolvimento Cientifico e Tecnológico (CNPq) (Grants 48.0040/2004-4 and 55.8470/2005-0) and the Comissão Interministerial para os Recursos do Mar (CIRM). We would like to thank the Brazilian Navy for logistical support, the crew of the fishing boats Transmar I and Transmar II and all the biologists and aquaculture engineers who helped during field work and plankton analysis in the laboratory. We would also like to thank Luis Carlos P. Macedo-Soares (ECZ/UFSC) for drawing the maps.

\section{References}

Anger K (2001) The biology of decapod crustacean larvae. A.A. Balkema Publishers, Lisse

Arístegui J, Sangrá P, Hernández-León S, Cantón M, HernándezGuerra A, Kerling JL (1994) Island-induced eddies in the Canary Islands. Deep-Sea Res I 41:1509-1525

Boehlert G, Watson W, Sun LC (1992) Horizontal and vertical distributions of larval fishes around an isolated oceanic island in the tropical Pacific. Deep-Sea Res I 39:439-466

Boltovskoy D (1981) Atlas del Atlantico Sudoccidental y métodos de trabajo con el zooplancton marino. INIDEP, Mar del Plata

Calazans D (1994) Morphology, abundance and distribution of larval phases of two Sergestids in the Southern Brazilian coast. Nauplius 2:75-86

Christy JH (1982) Adaptive significance of semilunar cycles of larval release in fiddler crabs (Genus $U c a$ ): test of a hypothesis. Biol Bull 163:251-263

Cowen RK, Sponaugle S (2008) Larval dispersal and marine population connectivity. Annu Rev Mar Sci 1:443-466

Cuesta JA, Rodríguez A (2000) Zoeal stages of the intertidal crab Pachygrapsus marmoratus (Fabricius, 1787) (Brachyura, Grapsidae) reared in the laboratory. Hydrobiologia 436:119-130

Cuesta JA, Guerao G, Schubart CD, Anger K (2011) Morphology and growth of the larval stages of Geograpsus lividus (Crustacea, Brachyura), with the descriptions of new larval characters for the Grapsidae and an undescribed setation pattern in extended developments. Acta Zool 92:225-240

Edwards AJ, Lubbock R (1983a) The ecology of Saint Paul's Rocks (Equatorial Atlantic). J Zool 200:51-69

Edwards AJ, Lubbock R (1983b) Marine zoogeography of St Paul's Rocks. J Biogeogr 10:65-72

Feitoza BM, Rocha LA, Luiz-Jr OJ, Floeter SR, Gasparini JL (2003) Reef fishes of St. Paul's Rocks: new records and notes on biology and zoogeography. Aqua J Ichthyol Aquat Biol 7:61-82

Flores AAV, Mazzuco ACA, Bueno M (2007) A field study to describe diel, tidal and semilunar rhythms of larval release in an assemblage of tropical rocky shore crabs. Mar Biol 151:1989-2002

Fogarty MJ, Botsford LW (2006) Metapopulation dynamics of coastal decapods. In: Kritzer JP, Sale PF (eds) Marine metapopulations. Elsevier, San Diego, pp 271-319

Freire AS, Pinheiro MAA, Karam-Silva H, Teschima MM (2011) Biology of Grapsus grapsus (Linnaeus, 1758) (Brachyura, Grapsidae) in the Saint Peter and Saint Paul Archipelago, Equatorial Atlantic Ocean. Helgol Mar Res 65:263-273

Genin A (2004) Bio-physical coupling in the formation of zooplankton and fish aggregations over abrupt topographies. J Mar Syst 50:3-20

Guerao G, Schubart CD, Cuesta JA (2001) The first zoeal stages of Grapsus grapsus (Linnaeus) and Geograpsus lividus (H. Milne
Edwards) (Decapoda, Brachyura, Grapsidae) from the western Atlantic. Nauplius 9:111-121

Gurney R, Lebour MV (1940) Larvae of Decapod Crustacea. Part VI. The Genus Sergestes. Disc Rep 20:1-68

Holthuis LB, Edwards AJ, Lubbock HR (1980) The decapod and stomatopod Crustacea of St. Paul's Rocks. Zool Meded 56:27-51

Hovel KA, Morgan SG (1997) Planktivory as a selective force for reproductive synchrony and larval migration. Mar Ecol Prog Ser 157:79-95

Koettker AG, Freire AS, Sumida PYG (2010) Temporal, diel and spatial variability of decapod larvae from St Paul's Rocks, an equatorial oceanic island of Brazil. J Mar Biol Ass U K 90:1227-1239

Landeira JM, Lozano-Soldevilla F, Hernández-León S, Barton ED (2009) Horizontal distribution of invertebrate larvae around the oceanic island of Gran Canaria: the effect of mesoscale variability. Sci Mar 73:761-771

Landeira JM, Lozano-Soldevilla F, Hernández-León S, Barton ED (2010) Spatial variability of planktonic invertebrate larvae in the Canary Islands area. J Mar Biol Ass U K 90:1217-1225

Levin LA (2006) Recent progress in understanding larval dispersal: new directions and digressions. Integr Comp Biol 46:282-297

Macedo-Soares LCP, Freire AS, Muelbert JH (2012) Small-scale spatial and temporal variability of larval fish assemblages at an isolated oceanic island. Mar Ecol Prog Ser 444:207-222

McEwan GE, Johnson MW, Folsom TR (1954) A statistical analysis of the performance of the Folsom plankton splitter, based upon test observation. Meteorol Atmos Phys 7:502-527

Medeiros C, Araújo M, Freitas I, Rollnic M (2009) Massas d'água da região oeste do Atlântico Tropical. In: Hazin FHV (ed) Meteorologia e Sensoriamento Remoto, Oceanografia Física, Oceanografia Química e Oceanografia Geológica (Programa Revizee-Score Nordeste). Martins \& Cordeiro, Fortaleza, pp 56-69

Melo GAS (1996) Manual de identificação dos Brachyura (Caranguejos e Siris) do litoral Brasileiro. Plêiade/FAPESP, São Paulo

Morgan SG (1990) Impact of planktivorous fishes on dispersal, hatching, and morphology of estuarine crab larvae. Ecology 71:1640-1652

Morgan SG, Christy JH (1997) Planktivorous fishes as selective agents for reproductive synchrony. J Exp Mar Biol Ecol 209:89-101

Morgan SG, Fisher JL (2010) Larval behavior regulates nearshore retention and offshore migration in an upwelling shadow and along the open coast. Mar Ecol Prog Ser 404:109-126

Morgan SG, Fisher JL, Miller SH, McAfee ST, Largier JL (2009) Nearshore larval retention in a region of strong upwelling and recruitment limitation. Ecology 90:3489-3502

Mujica A (2006) Larvas de crustáceos decápodos y crustáceos holoplanctónicos en torno a la isla de Pascua. Cienc Tecnol Mar (CONA) 29:123-135

Mujica A, Nava ML, Araya A (2011) Larvas de Sergestes arcticus Krøyer, 1855, Neotrypaea uncinata (H. Milne-Edwards, 1837) y Munida gregaria (Fabricius, 1793), entre el seno Reloncaví y Boca del Guafo, sur de Chile. Lat Am J Aquat Res 39:33-42

Omori M (1974) The biology of pelagic shrimps in the ocean. Adv Mar Biol 12:233-324

Pakhomov EA, Froneman PW (2000) Composition and spatial variability of macroplankton and micronekton within the Antarctic Polar Frontal Zone of the Indian Ocean during austral autumn 1997. Polar Biol 23:410-419

Pascual M, Caswell H (1991) The dynamics of a size-classified benthic population with reproductive subsidy. Theor Pop Biol 39:129-147

Pérez V, Fernández E, Marañón E, Serret P, García-Soto C (2005) Seasonal and interannual variability of chlorophyll $a$ and 
primary production in the Equatorial Atlantic: in situ and remote sensing observations. J Plankton Res 27:189-197

Queiroga H, Blanton J (2004) Interactions between behavior and physical forcing in the control of horizontal transport of decapod crustacean larvae. Adv Mar Biol 47:107-214

Sastry AN (1983) Ecological aspects of reproduction. In: Vernberg JJ, Vernberg WB (eds) The biology of crustacea, vol 8. Academic Press, New York, pp 179-270

Schwamborn R, Ekau W, Silva AP, Silva TA, Saint-Paul U (1999) The contribution of estuarine decapod larvae to marine zooplankton communities in North-East Brazil. Arch Fish Mar Res 47:167-182

Sichel SE, Esperança S, Motoki A, Maia M, Horan MF, Szatmari P, Alves EC, Mello SLM (2008) Geophysical and geochemical evidence for cold upper mantle beneath the equatorial Atlantic Ocean. Rev Bras Geof 26:69-86
Sponaugle S, Cowen RK, Shanks A, Morgan SG, Leis JM, Pineda J, Boehlert GW, Kingsford MJ, Lindeman KC, Grimes C, Munro JL (2002) Predicting shelf recruitment in marine populations: biophysical correlates and mechanisms. Bull Mar Sci 70:341-375

Stramma L, Schott F (1999) The mean flow field of the tropical Atlantic Ocean. Deep-Sea Res II 46:279-303

Underwood AJ (2006) Experiments in ecology. Cambridge University Press, Cambridge

Yamaguchi T (2001) Daytime larval release of the fiddler crab, Uca lactea (Decapoda, Brachyura, Ocypodidae). Crustac Int J Crustac Res 74:545-555

Zar JH (1996) Biostatistical analysis. Prentice Hall International editions, New Jersey 